\title{
Conjugated Linoleic Acid Increases in Milk from Cows Fed Condensed Corn Distillers Solubles and Fish Oil ${ }^{1}$
}

\author{
M. Bharathan, ${ }^{\star 2}$ D. J. Schingoethe, ${ }^{\star 3}$ A. R. Hippen, ${ }^{\star}$ K. F. Kalscheur, ${ }^{\star}$ M. L. Gibson, $\dagger$ and K. Karges $\dagger$ \\ *Dairy Science Department, South Dakota State University, Brookings 57007-0647 \\ †Poet Nutrition, Sioux Falls, SD 57104
}

\begin{abstract}
Twelve lactating Holstein cows were randomly assigned to 1 of 4 experimental diets in a replicated $4 \times$ 4 Latin square design with 4 -wk periods to ascertain the lactational response to feeding fish oil (FO), condensed corn distillers solubles (CDS) as a source of extra linoleic acid, or both. Diets contained either no FO or $0.5 \%$ FO and either no CDS or $10 \%$ CDS in a $2 \times 2$ factorial arrangement of treatments. Diets were fed as total mixed rations for ad libitum consumption. The forage to concentrate ratio was $55: 45$ on a dry matter basis for all diets and the diets contained $16.2 \%$ crude protein. The ether extract concentrations were 2.86, 3.22, 4.77, and $5.02 \%$ for control, FO, CDS, and FOCDS diets, respectively. Inclusion of FO or CDS or both had no effect on dry matter intake, feed efficiency, body weight, and body condition scores compared with diets without FO and CDS, respectively. Yields of milk (33.3 kg/d), energy-corrected milk, protein, lactose, and milk urea $\mathrm{N}$ were similar for all diets. Feeding FO and CDS decreased milk fat percentages $(3.85,3.39,3.33$, and $3.12 \%$ ) and yields compared with diets without FO and CDS. Proportions of trans-11 C18:1 (vaccenic acid), cis9 trans-11 conjugated linoleic acid (CLA; 0.52, 0.90, 1.11 , and $1.52 \mathrm{~g} / 100 \mathrm{~g}$ of fatty acids), and trans-10 cis12 CLA (0.07, 0.14, 0.13, and $0.16 \mathrm{~g} / 100 \mathrm{~g}$ of fatty acids) in milk fat were increased by FO and CDS. No interactions were observed between FO and CDS on cis-9 trans-11 CLA although vaccenic acid tended to be higher with the interaction. The addition of CDS to diets increased trans-10 C18:1. Greater ratios of vaccenic acid to cis-9 trans-11 CLA in plasma than in milk fat indicate tissue synthesis of cis-9 trans-11 CLA in the mammary gland from vaccenic acid in cows fed FO
\end{abstract}

\footnotetext{
Received December 11, 2007.

Accepted February 26, 2008.

${ }^{1}$ Published with the approval of the director of the South Dakota Agricultural Experiment Station as Publication Number 3618 of the Journal series.

${ }^{2}$ Current address: Dairy Science Department, Virginia Polytechnic Institute and State University, Blacksburg 24061.

${ }^{3}$ Corresponding author: david.schingoethe@sdstate.edu
}

or CDS. Feeding fish oil at $0.5 \%$ of diet dry matter with a C18:2 n-6 rich source such as CDS increased the milk CLA content but decreased milk fat percentages.

Key words: fish oil, condensed corn distillers solubles, conjugated linoleic acid, cow

\section{INTRODUCTION}

Studies conducted at South Dakota State University showed that the conjugated linoleic acid (CLA) content of milk fat from cows fed sources of n-6 fatty acids such as linoleic and linolenic acids can be further increased by feeding fish oil (FO) in combination with the plant oils and the increase in CLA was more than the additive effect of the FO and plant oils high in linoleic acid (Whitlock et al., 2002; AbuGhazaleh et al., 2003a). Fish oil is more effective than plant oils to increase cis-9 trans-11 CLA in milk fat (Offer et al., 1999; Donovan et al., 2000; Chouinard et al., 2001).

Fish oil contains virtually no CLA but stimulates rumen bacteria to make increased amounts of CLA from fat sources that are high in linoleic acid such as soybeans, sunflower seeds, and possibly corn oil found in CDS (AbuGhazaleh et al., 2002; Whitlock et al., 2002) and only a small amount of FO is needed with the high linoleic acid source (Whitlock et al., 2006). Greater amounts of the $n-6$ fatty acids linoleic, linolenic, as well as the n-3 fatty acids eicosapentaenoic acid (EPA; C20:5n-3) and docosahexaenoic acid (C22:6n-3), which are not synthesized in ruminant tissues, need to be supplied in diets for them and CLA to appear in milk in increased concentrations.

Byproducts of ethanol production include condensed corn distillers solubles (CDS), which provide an excellent source of energy, especially fat, and distillers grains with solubles (DGS); both are relatively inexpensive sources of protein and energy. The major fatty acid in CDS is linoleic acid, which accounts for approximately $52 \%$ of the total fatty acids (DaCruz et al., 2005; Sasikala-Appukuttan et al., 2008). Feeding 5 or $10 \%$ CDS to lactating cows increased production in the study by DaCruz et al. (2005); greater amounts may also be fed (Sasikala-Appukuttan et al., 2008). The objective of this 
research was to assess and compare the response in the CLA content of milk fat when CDS was fed with or without fish oil to lactating dairy cows. We hypothesized that feeding a small amount of fish oil (as a modifier of ruminal biohydrogenation) with a source of linoleic acid such as CDS (as a substrate) would increase the CLA content of the milk and the content of its precursor vaccenic acid (VA) more than feeding the CDS alone.

\section{MATERIALS AND METHODS}

\section{Experimental Plan}

This experiment was performed at South Dakota State University Dairy Research and Training Facility with all procedures conducted under approval of the South Dakota Animal Care and Use Committee. The objective of this experiment was to assess and compare the effect of feeding FO or CDS or both on DMI, milk production, and milk and plasma fatty acid composition. Twelve mid-lactation Holstein cows (8 multiparous and 4 primiparous), averaging $124( \pm 10)$ DIM at the start of the experiment were assigned to 1 of the 4 experimental diets in a replicated $4 \times 4$ Latin square design with a $2 \times 2$ factorial arrangement of treatments. Cows were blocked by parity, production, and DIM, and then, within blocks (squares), assigned at random to experimental diets. Each experimental period consisted of $4 \mathrm{wk}$, with wk 1 and 2 for adaptation and wk 3 and 4 for data collection. Cows were housed in a free-stall barn and adapted to Calan doors (American Calan Inc., Northwood, NH) 1 wk before start of the experiment. Diets were fed as TMR for ad libitum consumption using the Calan Broadbent feeder door and box system.

The experimental diets consisted of 1 ) control (no FO and no CDS), 2) control diet with $0.5 \%$ fish oil (FO), 3) control diet with 10\% CDS supplying $2 \%$ dietary fat (CDS), and 4) control diet with 10\% CDS and 0.5\% fish oil (FOCDS). All diets (Table 1) were balanced to provide recommended total daily nutrients for a dairy cow producing $45 \mathrm{~kg}$ of milk/d (NRC, 2001). Diets were formulated to contain $17 \% \mathrm{CP}$ using ground shelled corn and soybean meal as the base ingredients of the concentrate mix; CDS and FO replaced portions of these ingredients in the treatment diets. The FO (Menhaden) was included in the concentrate mix. The CDS was stored in a tank of approximately $1,100 \mathrm{~kg}$ capacity at the farm and mixed thoroughly by circulation for $1 \mathrm{~h}$ before incorporating into the diet. The proportion of diet ingredients was a 55:45 blend of forage and concentrate on a DM basis. The forage portion of all diets, containing $27.5 \%$ alfalfa hay and $27.5 \%$ corn silage (DM basis), was premixed in a mixer wagon (1999 NDE 500, Westside Implement, Clark, SD). Concentrate mix and CDS were added to the Calan Data Ranger (American
Table 1. Ingredient and formulated nutrient composition of experimental diets ${ }^{1}$

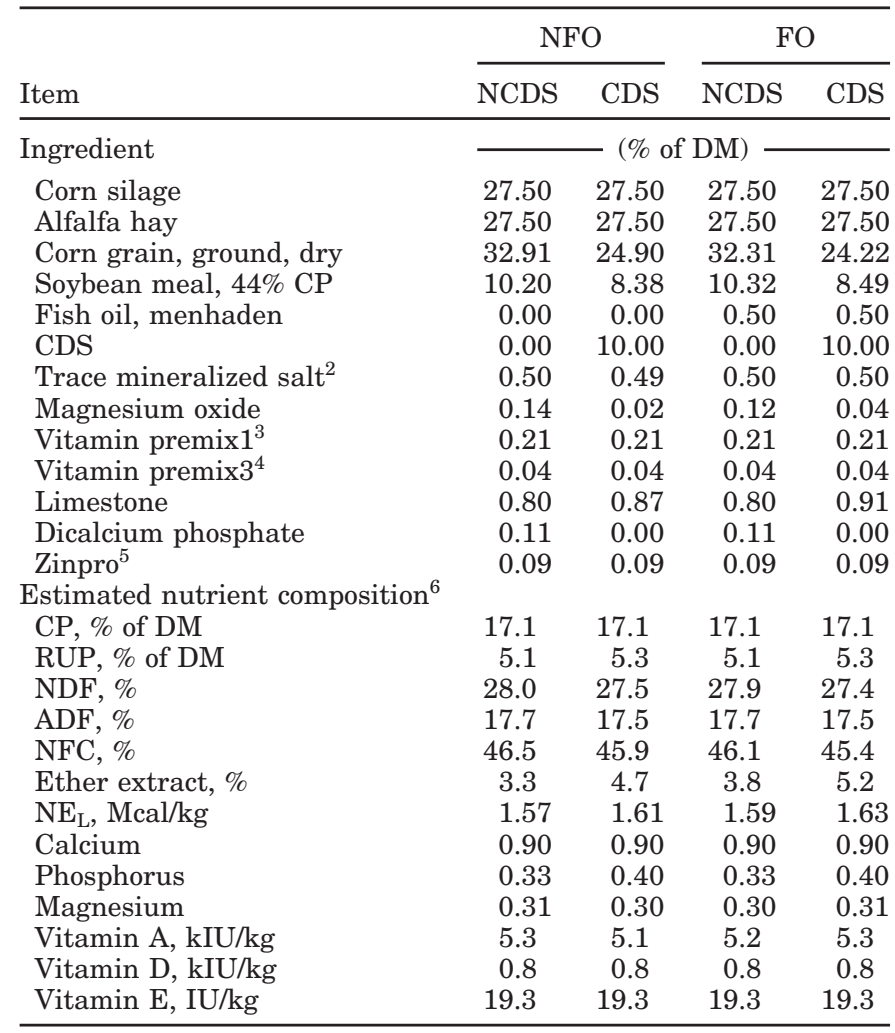

${ }^{1} \mathrm{NFO}=$ no fish oil $; \mathrm{FO}=0.5 \%$ fish oil; $\mathrm{NCDS}=$ no corn distillers solubles (CDS), and CDS $=10 \%$ CDS supplying $2 \%$ fat.

${ }^{2}$ Trace mineralized salt contained salt (as $\mathrm{NaCl}$ ) maximum, 985,000, minimum, 940,000 mg/kg; sodium (as Na), 387,000 mg/kg; iron (as Fe), 2,000 mg/kg; zinc (as Zn), 3,500mg/kg; manganese, 2, 000 $\mathrm{mg} / \mathrm{kg}$; copper, $300 \mathrm{mg} / \mathrm{kg}$; iodine, $70 \mathrm{mg} / \mathrm{kg}$; cobalt, $50 \mathrm{mg} / \mathrm{kg}$.

${ }^{3}$ Vitamin premix1: 2,500,000 IU/kg of vitamin A; 400,000 IU/kg of vitamin D; and 1,000 IU/kg of vitamin $\mathrm{E}$.

${ }^{4}$ Vitamin premix3: vitamin E, 44,000 IU/kg.

${ }^{5}$ Zinpro: $\mathrm{Cu}, 125 \mathrm{mg} / \mathrm{kg}$; Mn, $200 \mathrm{mg} / \mathrm{kg}$; Zn, $360 \mathrm{mg} / \mathrm{kg}$.

${ }^{6}$ Estimated from Dairy NRC (2001) (\% of DM unless otherwise noted).

Calan Inc.) after addition of premixed forages at the time of feeding. Cows were milked 3 times a day at 0600 , 1400 , and $2100 \mathrm{~h}$, with milk production recorded daily.

\section{Sample Collection and Analytical Procedures}

Feed intake for individual cows was measured daily using the Calan Broadbent feeder door system and Data Ranger. Samples of corn silage, alfalfa hay, concentrate mixes, FO, CDS, and each diet were collected weekly and stored at $-20^{\circ} \mathrm{C}$ until analysis. Dry matter concentrations were determined weekly on a portion of CDS, corn silage, and alfalfa hay by drying at $105^{\circ} \mathrm{C}$ for 2 to $4 \mathrm{~h}$ in a Despatch oven (style V-23, Despatch Oven Co., Minneapolis, MN) according to AOAC method 930.15 (AOAC, 2002). As-fed amounts of ingredients were ad- 
justed to ensure proper inclusion of CDS and corn silage. Composites were made for each period from the weekly samples and dried for $48 \mathrm{~h}$ at $55^{\circ} \mathrm{C}$ in a Despatch oven. Composites were then ground to 4-mm particle size (Wiley mill, model 3, Arthur H. Thomas Co., Philadelphia, PA), and ground further to 1-mm particle size using an ultracentrifuge mill (Brinkman Instruments Co., Westbury, NY). All feed samples except FO were analyzed for true DM, ash, NDF, ADF, lignin, ether extract, and CP. The CDS was analyzed for DM, ether extract, $\mathrm{CP}$, and minerals ( $\mathrm{Ca}, \mathrm{P}, \mathrm{K}, \mathrm{Mg}$, and $\mathrm{S})$. For correction to $100 \% \mathrm{DM}$ of feeds, true DM was obtained by drying approximately $1 \mathrm{~g}$ of ground sample at $105^{\circ} \mathrm{C}$ for more than $3 \mathrm{~h}$. Ash was determined by heating samples in a muffle furnace at $450^{\circ} \mathrm{C}$ for $8 \mathrm{~h}$ (Understander et al., 1993). The NDF, ADF, and lignin concentrations were determined using the Ankom fiber analysis system (Ankom Technology Corp., Fairport, NY), based on procedures of Van Soest et al. (1991) for NDF and $\mathrm{ADF}$ as described by Robertson and Van Soest (1981) using heat-stable $\alpha$-amylase and sodium sulfite. Acid detergent lignin was determined based upon procedures described by Lowry et al. (1994). Crude protein was determined by Kjeldahl method (AOAC, 2002; method 954.01). Ether extract was determined by method 920.39 (AOAC, 2002). Composites of ground samples of concentrate mix, alfalfa hay, corn silage, and complete diets were sent to Dairyland Laboratories Inc. (Arcadia, WI) for analysis of minerals $(\mathrm{Ca}, \mathrm{P}, \mathrm{K}$, $\mathrm{Mg}$, and S) by spectroscopic method and Corning 926 Direct Reading Chloride/Salt analyzer (AOAC, 2002; methods 965.09 and 985.01).

Milk samples were collected at all 3 milking times for 2 consecutive days during wk 3 (d 20 and 21) and 4 (d 27 and 28) of each period. Composites of milk samples were made by day and sent to Heart of American DHI Laboratory (Manhattan, KS) for analysis using AOAC (2002) approved methods. Analysis of milk fat, protein, and lactose were done by near infrared spectroscopy (Bentley 2000 Infrared Milk Analyzer, Bentley Instruments, Chaska, MN), while MUN concentration was determined using chemical methods based on a modified Berthelot reaction (Chaney and Marbach, 1962; ChemSpec 150 Analyzer, Bentley Instruments). Somatic cell counts were determined with a flow cytometer laser (Somacount 500, Bentley Instruments). Energycorrected milk was determined using the equation $[(0.327 \times \mathrm{kg}$ of milk $)+(12.95 \times \mathrm{kg}$ of fat $)+(7.2 \times \mathrm{kg}$ of protein)] (Orth, 1992).

Cows were weighed on 3 consecutive days before the beginning of the trial and on the last $3 \mathrm{~d}$ of each period. At the start of the trial and end of each period, BCS were recorded by 3 independent individuals. Body condition scores were based on a scale of 1 to 5 , with 5 represent- ing obese and 1 representing emaciated (Wildman et al., 1982).

Rumen fluid was collected on $2 \mathrm{~d}$ in wk 4 of each period, approximately $3 \mathrm{~h}$ postfeeding by applying vacuum pressure to an esophageal tube with a suction strainer on the rumen end. The first 200 to $300 \mathrm{~mL}$ of rumen fluid was discarded before sample collection to minimize contamination with saliva. Ten-milliliter aliquots of rumen fluid samples were mixed with $2 \mathrm{~mL}$ of $25 \%$ (wt/vol) meta-phosphoric acid and placed immediately into storage tubes and stored at $-20^{\circ} \mathrm{C}$ until analysis. Rumen liquor was analyzed for ammonia nitrogen concentration (Chaney and Marbach, 1962) and VFA (Ottenstein and Bartley, 1971) using GC (model 6890, Hewlett-Packard, Palo Alto, CA) with a flame-ionization detector. The injector port was at a temperature of $250^{\circ} \mathrm{C}$ with a split ratio of $100: 1$ using a column 15 $\mathrm{m}$ in length and $0.25 \mathrm{~mm}$ in diameter (Nukal, Supelco Inc., Bellefonte, PA). Flow rate was $1.3 \mathrm{~mL} / \mathrm{min}$ of helium, and the detector and column were maintained at 225 and $130^{\circ} \mathrm{C}$, respectively.

Blood samples were collected from a coccygeal vessel approximately $3 \mathrm{~h}$ after feeding on the last day of wh 4 of each period. Blood was drawn into $\mathrm{K}_{3}$ EDTA vacuum tubes (Becton Dickinson and Co., Franklin Lakes, NJ). The samples were immediately placed on ice and were taken to the laboratory where they were centrifuged $(500 \times g)$ for $20 \mathrm{~min}$ to separate the plasma. Plasma was stored at $-20^{\circ} \mathrm{C}$ until further analysis.

Fatty Acid Analysis. Feed fatty acids were extracted and prepared as butyl esters (Abu-Ghazaleh et al., 2002) for analysis using GC (model 6890, HewlettPackard, Palo Alto, CA). The samples were analyzed using a flame-ionization detector. The injector port was set at a temperature of $230^{\circ} \mathrm{C}$ with a split ratio of $100: 1$. The column was $100 \mathrm{~m}$ long and had an inside diameter of $0.25 \mathrm{~mm}$ (Supelco 2560, Supelco Inc.). The flow rate was $2.0 \mathrm{~mL} / \mathrm{min}$ of helium; the detector was maintained at $250^{\circ} \mathrm{C}$. Initial temperature was $50^{\circ} \mathrm{C}$ held for $1 \mathrm{~min}$, and then increased to $145^{\circ} \mathrm{C}$ at a rate of $5^{\circ} \mathrm{C} / \mathrm{min}$, and held for $30 \mathrm{~min}$. The temperature was then increased to $190^{\circ} \mathrm{C}$ at the rate of $10^{\circ} \mathrm{C} / \mathrm{min}$ and held for $30 \mathrm{~min}$, and finally, the temperature was increased $5^{\circ} \mathrm{C} / \mathrm{min}$ to $210^{\circ} \mathrm{C}$, and held for $35 \mathrm{~min}$. The total run per sample was 129 min and fatty acids were identified based on elution patterns of known fatty acids. Standard mixtures of fatty acids (FIM-FAME-7, Matreya Inc., Pleasant Gap, PA; and GLC-68D, Nu-Chek Prep Inc., Elysian, MN) and standards for cis-9 trans-11 and trans10 cis-12 CLA (Matreya Inc.) were analyzed for identification of the fatty acid elution positions.

Composites of milk samples for each of wk 3 and wk 4 were made for each cow and period and prepared for milk fatty acid composition analysis using an adapted 
method (Loor et al., 2005) originally described by Sukhija and Palmquist (1988), except that it was modified to form butyl esters (Abu-Ghazaleh et al., 2002). An internal standard C13:1 was used. The samples were then analyzed by GC (model 6890, Hewlett Packard) as described for feed fatty acids.

Plasma samples were analyzed for fatty acids using GC (model 6890, Hewlett-Packard). Fatty acids from 1 $\mathrm{mL}$ of whole plasma were butylated with n-butanol, followed by acetylation with acetyl chloride as described above without prior extraction. The fatty acid C13:1 was used as the internal standard. Samples were kept for incubation at $100^{\circ} \mathrm{C}$ for $90 \mathrm{~min}$, followed by the addition of $6 \%$ potassium carbonate and $1 \mathrm{~mL}$ of hexane at room temperature. Samples were centrifuged and washed 3 times with double distilled water. Fatty acid butyl esters recovered in $1 \mathrm{~mL}$ of hexane were transferred to a GC vial. Five microliters of butyl esters in hexane were injected at a 20:1 split ratio. The injector port was at a temperature of $250^{\circ} \mathrm{C}$ with a split ratio of 20:1.

\section{Statistical Analysis}

Weekly means of DMI, milk yield, milk composition, and fatty acid profiles of milk for each period were used for statistical analysis. Rumen liquor and blood collected on d 28 of each period were used for statistical analysis. The design of this experiment was a $4 \times 4$ Latin square with a $2 \times 2$ arrangement of treatments. The data were analyzed using the MIXED procedures of SAS (SAS Institute, 1999) with the model:

$$
\begin{aligned}
& \mathrm{Y}_{\mathrm{ijkl}}=\mu+ \mathrm{P}_{\mathrm{i}}+\mathrm{C}_{\mathrm{j}(\mathrm{Rm})}+\mathrm{FO}_{\mathrm{k}}+\mathrm{CDS}_{\mathrm{l}}+\left(\mathrm{FO}_{\mathrm{k}} \times \mathrm{CDS}_{\mathrm{l}}\right) \\
&+ \mathrm{R}_{\mathrm{m}}+\left(\mathrm{FO}_{\mathrm{k}} \times \mathrm{R}_{\mathrm{m}}\right)+\left(\mathrm{CDS}_{\mathrm{l}} \times \mathrm{R}_{\mathrm{m}}\right) \\
&+\left(\mathrm{FS}_{\mathrm{k}} \times \mathrm{CDS}_{\mathrm{l}} \times \mathrm{R}_{\mathrm{m}}\right)+\mathrm{e}_{\mathrm{ijk} \mathrm{m}}
\end{aligned}
$$

where $\mu=$ overall mean, $P_{i}=$ effect of period ( $i=1$ to $4), \mathrm{C}_{\mathrm{j}(\mathrm{Rm})}=$ effect of cow nested within parity $(\mathrm{j}=1$ to 12), $\mathrm{FO}_{\mathrm{k}}=$ effect of $\mathrm{FO}(\mathrm{k}=1$ to 2$), \mathrm{CDS}_{\mathrm{l}}=$ effect of CDS $(\mathrm{l}=1$ to 2$),\left(\mathrm{FO}_{\mathrm{k}} \times \mathrm{CDS}_{\mathrm{l}}\right)=$ interaction of $\mathrm{FO}_{\mathrm{k}}$ and $\mathrm{CDS}_{\mathrm{l}}, \mathrm{R}_{\mathrm{m}}=$ effect of parity $(\mathrm{m}=1$ to 2$),\left(\mathrm{FO}_{\mathrm{k}} \times \mathrm{R}_{\mathrm{m}}\right)=$ interaction of $\mathrm{FO}_{\mathrm{k}}$ and parity $\mathrm{m},\left(\mathrm{CDS}_{\mathrm{l}} \times \mathrm{R}_{\mathrm{m}}\right)=$ interaction of CDSl and parity $\mathrm{m},\left(\mathrm{FO}_{\mathrm{k}} \times \mathrm{CDS}_{\mathrm{l}} \times \mathrm{R}_{\mathrm{m}}\right)=$ interaction of $\mathrm{FO}_{\mathrm{k}}, \mathrm{CDS}_{\mathrm{l}}$, and parity $\mathrm{m}$, and $\mathrm{e}_{\mathrm{ijklm}}=$ random residual error. Cow within parity was the random effect. Parity remained in the model for all variables, although interactions with parity that were not significant were dropped from the model. There were no interactions of main effects with period for any variable; therefore, they were not included in the model. Significance was declared at $P<0.05$, and tendency was indicated at $P<0.10$.

\section{RESULTS AND DISCUSSION}

\section{Nutrient Content of Diets}

Nutrient composition of diet components and TMR are shown in Table 2. Dry matter content of the diets varied from 55.8 to $45.5 \%$. As expected, inclusion of CDS in diets decreased the DM content to $45.5 \%$ and remained similar among CDS diets. Diets were formulated to be isonitrogenous (17\%); however, analyses were slightly lower at 16.2 to $16.3 \% \mathrm{CP}$, because of less protein in the alfalfa hay than anticipated. Diets were similar in NDF, ADF, and lignin. As intended, the ether extract contents were higher for diets containing FO and CDS. Fatty acid compositions of TMR, concentrate mixes, forages, FO, and CDS (Table 3) were typical of what was expected. The fat in CDS was approximately $52 \% \mathrm{C} 18: 2$, the major precursor for CLA. The n-3 fatty acids $\mathrm{C} 22: 5$ and $\mathrm{C} 22: 6$ were detected only in FO diets.

\section{DMI, Milk Yield, and Milk Composition}

The impact of diets on DMI, milk yield, and milk composition is presented in Table 4. Dry matter intakes were similar among diets, even when FO was added to the diets. This result was consistent with other studies (Whitlock et al., 2006) that used small amounts of fish oil with extruded soybeans. Feeding higher amounts of fish oil has been shown to have a negative effect on DMI (Donovan et al., 2000; Whitlock et al., 2002). Da Cruz et al. (2005) and Sasikala-Appukuttan et al. (2008) observed similar DMI for cows fed 10\% CDS or control diets. No significant effect on DMI was observed with supplementation of both FO and CDS, although DMI was numerically the least with that diet.

Milk production was similar $(P>0.05)$ for all diets, which was consistent with the fact that the DMI did not differ among treatments. Previous research by Whitlock et al. (2002) observed no effect on milk production when FO and extruded soybeans were added to the diet. This result is also in accordance with the findings of Da Cruz et al. (2005) and Sasikala-Appukuttan et al. (2008) when they fed $10 \%$ CDS to lactating dairy cows.

Milk fat percentage and milk fat yield decreased $(P$ $<0.01$ ) in cows fed FO compared with those not fed FO (3.26 vs. $3.59 \%)$. Decreased milk fat percentage and fat yield $(P<0.01$ and 0.04 , respectively) were observed for cows fed CDS compared with cows not fed CDS (3.23 vs. $3.62 \%)$. These results agreed with the findings of previous research with CDS (Da Cruz et al., 2005). When FO is fed to dairy cows, milk fat depression is usually observed (Cant et al., 1997; Donovan et al., 2000). Inclusion of FO or CDS or both to the diets resulted in lowered milk fat percentage, which may be 
Table 2. Nutrient compositions of the diets, ${ }^{1}$ concentrate mixes, ${ }^{1}$ alfalfa hay, corn silage, and condensed corn distillers solubles (CDS)

\begin{tabular}{|c|c|c|c|c|c|c|c|c|c|c|c|}
\hline \multirow[b]{3}{*}{ Item } & \multicolumn{4}{|c|}{ Diet } & \multicolumn{4}{|c|}{ Concentrate $\mathrm{mix}^{2}$} & \multirow{3}{*}{$\begin{array}{c}\text { Alfalfa } \\
\text { hay }\end{array}$} & \multirow{3}{*}{$\begin{array}{c}\text { Corn } \\
\text { silage }\end{array}$} & \multirow[b]{3}{*}{ CDS } \\
\hline & \multicolumn{2}{|c|}{$\mathrm{NFO}$} & \multicolumn{2}{|c|}{$\mathrm{FO}$} & \multicolumn{2}{|c|}{$\mathrm{NFO}$} & \multicolumn{2}{|c|}{ FO } & & & \\
\hline & NCDS & CDS & NCDS & CDS & NCDS & CDS & NCDS & CDS & & & \\
\hline $\mathrm{DM}^{3}$ & 55.8 & 44.5 & 53.9 & 44.5 & 88.9 & 89.3 & 88.3 & 89.6 & 88.3 & 27.7 & 27.5 \\
\hline $\mathrm{CP}^{3}$ & 16.2 & 16.2 & 16.2 & 16.3 & 19.0 & 18.1 & 19.0 & 18.4 & 19.2 & 8.6 & 24.5 \\
\hline $\mathrm{NDF}^{3}$ & 29.9 & 29.9 & 30.0 & 29.6 & 8.0 & 8.7 & 8.3 & 8.1 & 46.3 & 49.3 & 0.0 \\
\hline $\mathrm{ADF}^{3}$ & 17.9 & 17.9 & 17.9 & 17.9 & 2.8 & 2.9 & 2.9 & 2.7 & 31.9 & 28.5 & 0.0 \\
\hline $\operatorname{Lignin}^{3}$ & 2.18 & 2.66 & 2.59 & 3.00 & 0.00 & 0.00 & 0.00 & 0.00 & 6.52 & 2.83 & 0.0 \\
\hline Ether extract ${ }^{3}$ & 2.86 & 4.77 & 3.22 & 5.02 & 2.67 & 2.92 & 3.48 & 4.1 & 2.03 & 3.95 & 22.0 \\
\hline $\mathrm{Ash}^{3}$ & 6.98 & 7.81 & 6.79 & 7.62 & 7.14 & 7.98 & 6.99 & 8.07 & 8.32 & 4.83 & 11.5 \\
\hline Calcium $^{4}$ & 1.15 & 0.99 & 1.10 & 0.89 & 1.44 & 1.57 & 1.59 & 1.65 & 0.89 & 0.29 & 0.09 \\
\hline Phosphorus ${ }^{4}$ & 0.33 & 0.46 & 0.32 & 0.44 & 0.37 & 0.35 & 0.41 & 0.34 & 0.44 & 0.28 & 1.69 \\
\hline Magnesium $^{4}$ & 0.30 & 0.31 & 0.27 & 0.30 & 0.35 & 0.20 & 0.36 & 0.23 & 0.30 & 0.21 & 0.90 \\
\hline Potassium $^{4}$ & 1.14 & 1.41 & 1.14 & 1.37 & 0.66 & 0.73 & 0.70 & 0.75 & 1.37 & 1.05 & 2.47 \\
\hline Sulfur ${ }^{4}$ & 0.17 & 0.35 & 0.16 & 0.33 & 0.15 & 0.17 & 0.16 & 0.17 & 0.33 & 0.12 & 1.96 \\
\hline
\end{tabular}

${ }^{1} \mathrm{NFO}=$ no fish oil $; \mathrm{FO}=0.5 \%$ fish oil CDS $=10 \% \mathrm{CDS} ; \mathrm{NCDS}=$ no CDS.

${ }^{2}$ Fish oil was included in the concentrate mix; CDS was not included in the concentrate mix; it was added to the TMR directly.

${ }^{3}$ Average of results of analysis of samples from each period $(n=16)$.

${ }^{4}$ Results of analysis of sample composites from the entire trial $(n=4)$.

due to the rapid availability of oil in the rumen and its potential effect on fiber digestibility (Jenkins and Jenny, 1989). Ruminal VFA data (reported later) did not indicate differences in fiber digestibility, although that was not measured. The oil in CDS is likely more available to interfere with ruminal fiber digestibility and to be more available for ruminal biohydrogenation than is the oil in DGS. This may be why milk fat depression may occur when feeding CDS but does not usually occur when feeding DGS in diets that contain sufficient amounts of forage fiber (Anderson et al., 2006).

Milk protein percentage was not affected by the addition of FO, although CDS tended $(P=0.10)$ to decrease milk protein percentage. Milk protein yield and MUN were not affected by the addition of FO or CDS to the diets.

The addition of FO did not affect milk lactose percentage; however, addition of CDS to the diets decreased milk lactose percentage $(P<0.05)$ only when also in the presence of FO, but the lactose yield was not affected by the addition of FO or CDS or both to the diets. Although some of the above values were statistically significant, the numerical values were very small and likely not biologically significant.

The addition of FO, CDS, or both did not affect feed efficiency. However, feed efficiency for multiparous cows fed CDS was greater $(P<0.05)$ than for primiparous cows fed CDS (1.65 vs. 1.37, respectively). This likely reflected that a portion of the diet fed to primiparous cows was used for growth rather than for milk, and may indicate that multiparous cows have been mobilizing more tissues (NRC, 2001).

\section{Fatty Acid Composition of Milk}

Inclusion of FO, CDS, or both in the diets resulted in marked changes in fatty acid composition of milk fat (Table 5). The total concentration of saturated fatty acids decreased $(P=0.01)$ from 64.7 to $62.1 \mathrm{~g} / 100 \mathrm{~g}$ of fatty acids fed FO and decreased $(P<0.01)$ from 66.4 to $60.4 \mathrm{~g} / 100 \mathrm{~g}$ of fatty acids when fed CDS. These results were expected because inclusion of C18:2-rich sources like CDS in dairy cow diets often increases the unsaturated fatty acid concentration in milk fat (Sasikala-Appukuttan et al., 2008). Other studies also documented the increase in unsaturated fatty acids in milk fat by the addition of FO or C18:2-rich sources such as extruded soybeans (Schingoethe et al., 1996; Abu-Ghazaleh et al., 2002; Whitlock et al., 2002). In this study, $2 \%$ of fat in the CDS diets supplied as CDS (rich in C18:2) contributed to the increase in total unsaturated fatty acids in these diets.

Supplementation with FO or CDS decreased $(P<$ $0.05)$ the concentrations of short-chain fatty acids (C6:0 to $\mathrm{C} 10: 0)$. The concentration of medium-chain fatty acids in the milk fat (C11:0 to C17:1) did not differ with FO, whereas CDS decreased $(P<0.01)$ the concentration of medium-chain fatty acids. Similar responses in medium-chain fatty acids concentration especially in C12:0, C14:0, and C16:0 were reported by DaCruz et 
Table 3. Fatty acid compositions of diets, ${ }^{1}$ concentrate mixes, ${ }^{1}$ alfalfa hay, corn silage, condensed corn distillers solubles (CDS), and fish oil

\begin{tabular}{|c|c|c|c|c|c|c|c|c|c|c|c|c|}
\hline \multirow[b]{3}{*}{ Fatty acids ${ }^{2}$} & \multicolumn{4}{|c|}{ Diet } & \multicolumn{4}{|c|}{ Concentrate $\operatorname{mix}^{3}$} & \multirow{3}{*}{$\begin{array}{c}\text { Alfalfa } \\
\text { hay }\end{array}$} & \multirow{3}{*}{$\begin{array}{c}\text { Corn } \\
\text { silage }\end{array}$} & \multirow[b]{3}{*}{ CDS } & \multirow[b]{3}{*}{ Fish oil } \\
\hline & \multicolumn{2}{|c|}{$\mathrm{NFO}$} & \multicolumn{2}{|c|}{ FO } & \multicolumn{2}{|c|}{$\mathrm{NFO}$} & \multicolumn{2}{|c|}{ FO } & & & & \\
\hline & NCDS & CDS & NCDS & CDS & NCDS & CDS & NCDS & CDS & & & & \\
\hline $14: 0$ & 1.41 & 1.12 & 1.72 & 1.08 & 0.21 & 0.18 & 4.08 & 5.32 & 1.16 & 0.39 & 0.07 & 13.74 \\
\hline $15: 0$ & 0.11 & 0.16 & 0.22 & 0.17 & 0.05 & 0.18 & 0.32 & 0.45 & 0.49 & 0.21 & 0.01 & 1.03 \\
\hline $16: 0$ & 16.30 & 16.74 & 17.68 & 16.68 & 22.47 & 23.64 & 25.70 & 25.13 & 28.94 & 16.74 & 14.91 & 19.91 \\
\hline 7.0 & 0.18 & 0.15 & 0.23 & 0.21 & 5.95 & 6.24 & 6.83 & 0.48 & 0.42 & 0.19 & 0.07 & 0.71 \\
\hline C18:0 & 3.48 & 2.32 & 2.58 & 2.32 & 3.09 & 3.37 & 3.64 & 3.83 & 3.63 & $\mathrm{ND}^{4}$ & 1.91 & 3.51 \\
\hline $\mathrm{C} 18: 1$ trans- 6 & 0.30 & 0.21 & 0.22 & 0.24 & 1.41 & 0.13 & 0.11 & 0.10 & 0.48 & 1.16 & ND & 0.12 \\
\hline $\mathrm{C} 18: 1$ tra & ND & 0.12 & ND & 0.13 & ND & ND & ND & ND & 0.33 & 0.09 & ND & 0.10 \\
\hline & 17.08 & 19.92 & 15.32 & 18.84 & 21.88 & 23.80 & 22.32 & 21.85 & 5.23 & 13.93 & 26.87 & 7.11 \\
\hline & 0.86 & 0.83 & 1.14 & 1.08 & 1.07 & 1.12 & 1.68 & 1.88 & 0.98 & & 0.91 & 4.31 \\
\hline C18:2 & 35.46 & 39.50 & 31.39 & 37.59 & 33.06 & 34.58 & 28.75 & 30.77 & 20.72 & 33.45 & 52.41 & 1.81 \\
\hline C18:3n-6 & 0.95 & 0.82 & 1.09 & 0.91 & 0.51 & 0.57 & 0.44 & 0.69 & 5.05 & 0.79 & ND & 0.59 \\
\hline C & 0.67 & 0.54 & 0.57 & 0.55 & 1.14 & 0.62 & 0.52 & 0.53 & 1.22 & ND & 0.40 & 0.57 \\
\hline $3 n-$ & 8.33 & 6.46 & 10.22 & 7.24 & 5.25 & 3.34 & 2.74 & 4.66 & 23.63 & 10.95 & 0.04 & 1.70 \\
\hline $20:$ & 7.49 & 6.34 & 6.83 & 6.03 & 0.12 & ND & 0.26 & 0.30 & ND & 0.57 & 0.11 & 1.00 \\
\hline $\mathrm{C} 20: 2$ & 0.27 & 0.23 & 0.28 & 0.21 & ND & 0.18 & ND & 0.15 & 1.05 & ND & 0.04 & 0.35 \\
\hline C20:3 & ND & ND & ND & ND & ND & ND & ND & ND & 0.56 & 0.20 & 0.71 & 0.39 \\
\hline תח & 0.59 & 0.54 & 0.71 & 0.57 & 0.48 & 0.59 & 0.53 & 0.60 & 3.10 & ND & 0.51 & 1.20 \\
\hline 22 & 0 & 0.09 & 0.27 & 0.09 & ND & ND & ND & 0.11 & 0.19 & $\mathrm{~N}$ & 0.05 & 0.37 \\
\hline C20: & 0.31 & 0.28 & 1.33 & 1.00 & ND & ND & 0.44 & 1.16 & 1.40 & ND & 0.08 & 19.90 \\
\hline C22:2 & 3.10 & 2.88 & 3.98 & 3.52 & ND & ND & ND & ND & ND & 20.73 & ND & ND \\
\hline C24:0 & 1.16 & 0.32 & 0.23 & 0.26 & 0.57 & 0.90 & 0.86 & 0.80 & $\mathrm{~N}$ & ND & 0.35 & 0.51 \\
\hline & 0.28 & 0.31 & 0.35 & 0.29 & 0.28 & 0.26 & 0.20 & 0.33 & 0.93 & $\mathrm{~N}$ & 0.23 & 0.09 \\
\hline $\mathrm{C} 22: 4$ & ND & 0.15 & ND & 0.12 & ND & 0.30 & ND & 0.32 & $\mathrm{NI}$ & $\mathrm{N} 1$ & 0.30 & 0.89 \\
\hline C24:1 & 1.57 & ND & 2.06 & ND & 2.46 & ND & ND & ND & 0.49 & ND & ND & 0.49 \\
\hline $\mathrm{C} 22: 5 \mathrm{n}$ & ND & ND & 0.33 & 0.13 & 0.00 & 0.00 & 0.00 & 0.00 & ND & ND & ND & 3.33 \\
\hline $\mathrm{C} 22: 6 n-3$ & ND & ND & 1.24 & 0.75 & 0.00 & 0.00 & 0.58 & 0.56 & ND & ND & ND & 16.29 \\
\hline
\end{tabular}

${ }^{1} \mathrm{NFO}=$ no fish oil $; \mathrm{FO}=0.5 \%$ fish oil CDS $=10 \% \mathrm{CDS} ; \mathrm{NCDS}=$ no $\mathrm{CDS}$.

${ }^{2}$ Expressed as number of carbons: number of double bonds.

${ }^{3}$ Fish oil was included in the concentrate mix; CDS was not included in the concentrate mix; it was added to the TMR directly.

${ }^{4} \mathrm{ND}=$ not detectable.

Table 4. Least squares means for DMI, feed efficiency (FE), milk yield, milk composition, BW, and BCS of dairy cows fed experimental diets ${ }^{1}$

\begin{tabular}{|c|c|c|c|c|c|c|c|c|}
\hline \multirow[b]{2}{*}{ Item } & \multicolumn{2}{|c|}{$\mathrm{NFO}$} & \multicolumn{2}{|c|}{ FO } & \multirow[b]{2}{*}{ SEM } & \multicolumn{3}{|c|}{ Effect $^{2}(P$-value $)$} \\
\hline & NCDS & CDS & NCDS & CDS & & $\mathrm{FO}$ & CDS & $\mathrm{FO} \times \mathrm{CDS}$ \\
\hline DMI, kg/d & 25.0 & 24.7 & 25.3 & 23.4 & 1.64 & 0.60 & 0.31 & 0.42 \\
\hline Milk, kg/d & 32.6 & 35.0 & 33.2 & 32.3 & 2.32 & 0.42 & 0.57 & 0.19 \\
\hline $3.5 \% \mathrm{FCM}, \mathrm{kg} / \mathrm{d}$ & 34.5 & 34.1 & 32.6 & 30.3 & 2.26 & 0.03 & 0.28 & 0.45 \\
\hline ECM, kg/d & 34.5 & 34.6 & 33.2 & 31.0 & 2.15 & 0.05 & 0.39 & 0.35 \\
\hline Fat, \% & 3.86 & 3.33 & 3.40 & 3.13 & 0.14 & $<0.01$ & $<0.01$ & 0.22 \\
\hline Fat, kg/d & 1.26 & 1.17 & 1.12 & 1.01 & 0.08 & $<0.01$ & 0.04 & 0.78 \\
\hline Protein, \% & 3.24 & 3.22 & 3.28 & 3.20 & 0.08 & 0.90 & 0.10 & 0.32 \\
\hline Protein, kg/d & 1.05 & 1.11 & 1.08 & 1.03 & 0.06 & 0.53 & 0.86 & 0.14 \\
\hline Lactose, $\%$ & 4.90 & 4.91 & 4.94 & 4.83 & 0.05 & 0.48 & 0.04 & 0.01 \\
\hline Lactose, $\mathrm{kg} / \mathrm{d}$ & 1.61 & 1.71 & 1.64 & 1.56 & 0.12 & 0.43 & 0.82 & 0.15 \\
\hline MUN, mg/dL & 11.42 & 11.03 & 11.35 & 11.02 & 0.60 & 0.92 & 0.40 & 0.95 \\
\hline $\mathrm{SCC}, \times 10^{3} / \mathrm{mL}$ & 59.9 & 49.3 & 51.5 & 56.7 & 1.38 & 0.98 & 0.81 & 0.48 \\
\hline $\mathrm{FE}^{3}$ & 1.40 & 1.52 & 1.33 & 1.41 & 0.11 & 0.25 & 0.25 & 0.77 \\
\hline $\mathrm{BW}, \mathrm{kg}$ & 653 & 652 & 667 & 657 & 19.00 & 0.36 & 0.56 & 0.63 \\
\hline $\mathrm{BCS}^{4}$ & 3.43 & 3.43 & 3.39 & 3.39 & 0.06 & 0.25 & 0.91 & 0.91 \\
\hline
\end{tabular}

${ }^{1} \mathrm{NFO}=$ no fish oil; $\mathrm{FO}=0.5 \%$ fish oil CDS $=10 \% \mathrm{CDS}$; NCDS $=$ no CDS.

${ }^{2} \mathrm{FO}=$ effect of fish oil (FO vs. NFO); CDS = effect of CDS (CDS vs. NCDS), FO $\times$ CDS = interaction of $\mathrm{FO}$ and CDS.

${ }^{3} \mathrm{FE}=\mathrm{kg}$ of $\mathrm{ECM} / \mathrm{kg}$ of DMI.

${ }^{4} 1=$ emaciated and $5=$ overly fat (Wildman et al., 1982). 
Table 5. Least squares means for fatty acid (FA) composition of milk fat from cows fed experimental diets ${ }^{1}$

\begin{tabular}{|c|c|c|c|c|c|c|c|c|}
\hline \multirow[b]{2}{*}{ Fatty acid $^{2}$} & \multicolumn{2}{|c|}{ NFO } & \multicolumn{2}{|c|}{ FO } & \multirow[b]{2}{*}{ SEM } & \multicolumn{3}{|c|}{ Effect $^{3}$ ( $P$-value $)$} \\
\hline & NCDS & CDS & NCDS & CDS & & FO & CDS & $\mathrm{FO} \times \mathrm{CDS}$ \\
\hline & \multicolumn{4}{|c|}{$-(\mathrm{g} / 100 \mathrm{~g}$ of fatty acids $)$} & & & & \\
\hline C4:0 & 2.00 & 1.97 & 1.94 & 1.88 & 0.08 & 0.20 & 0.47 & 0.77 \\
\hline C6:0 & 1.31 & 1.17 & 1.21 & 1.08 & 0.07 & 0.06 & 0.01 & 0.07 \\
\hline C8:0 & 1.66 & 1.39 & 1.51 & 1.26 & 0.09 & 0.04 & $<0.01$ & 0.81 \\
\hline C9:0 & 0.06 & 0.04 & 0.05 & 0.03 & 0.01 & 0.02 & $<0.01$ & 0.77 \\
\hline C10:0 & 4.14 & 3.19 & 3.65 & 2.88 & 0.22 & 0.02 & $<0.01$ & 0.60 \\
\hline C11:0 & 0.32 & 0.27 & 0.30 & 0.23 & 0.02 & 0.04 & $<0.01$ & 0.65 \\
\hline C11:1 & 0.13 & 0.08 & 0.10 & 0.06 & 0.01 & 0.01 & $<0.01$ & 0.52 \\
\hline C12:0 & 5.08 & 3.80 & 4.44 & 3.34 & 0.24 & 0.02 & $<0.01$ & 0.68 \\
\hline C12:1 & 0.14 & 0.10 & 0.12 & 0.09 & 0.01 & 0.04 & $<0.01$ & 0.80 \\
\hline C13:0 & 0.18 & 0.13 & 0.15 & 0.11 & 0.01 & 0.01 & 0.01 & 0.73 \\
\hline C14:0 & 13.28 & 11.89 & 12.87 & 11.64 & 0.40 & 0.36 & $<0.01$ & 0.82 \\
\hline $\mathrm{C} 14: 1 t$ & 0.22 & 0.17 & 0.21 & 0.17 & 0.01 & 0.11 & 0.01 & 0.77 \\
\hline $\mathrm{C} 14: 1 c$ & 1.66 & 1.69 & 1.67 & 1.68 & 0.09 & 0.99 & 0.83 & 0.89 \\
\hline C15:0 & 1.33 & 1.09 & 1.25 & 0.99 & 0.07 & 0.15 & $<0.01$ & 0.86 \\
\hline C15:1 & 0.26 & 0.22 & 0.26 & 0.27 & 0.03 & 0.37 & 0.59 & 0.44 \\
\hline C16:0 & 30.70 & 27.18 & 29.67 & 27.78 & 0.51 & 0.60 & $<0.01$ & 0.05 \\
\hline C16:1t & 0.20 & 0.20 & 0.21 & 0.22 & 0.01 & 0.02 & 0.49 & 0.35 \\
\hline $\mathrm{C} 16: 1 c$ & 1.95 & 1.96 & 2.20 & 2.22 & 0.13 & $<0.01$ & 0.90 & 0.96 \\
\hline C17:0 & 0.60 & 0.52 & 0.63 & 0.54 & 0.02 & 0.14 & $<0.01$ & 0.97 \\
\hline C17:1 & 0.03 & 0.02 & 0.03 & 0.03 & 0.00 & 0.04 & $<0.01$ & 0.45 \\
\hline C18:0 & 7.04 & 8.35 & 6.53 & 7.29 & 0.31 & $<0.01$ & $<0.01$ & 0.32 \\
\hline Total C18: $1^{4}$ & 20.30 & 25.83 & 21.93 & 26.19 & 1.02 & 0.26 & $<0.01$ & 0.47 \\
\hline Total C18:24 & 3.61 & 3.97 & 4.06 & 4.60 & 0.12 & $<0.01$ & $<0.01$ & 0.45 \\
\hline Total conjugated linoleic acid & 0.61 & 1.24 & 1.04 & 1.68 & 0.09 & $<0.01$ & $<0.01$ & 0.98 \\
\hline C18:3 $\gamma$ & 0.07 & 0.06 & 0.06 & 0.06 & 0.00 & $<0.01$ & 0.16 & $<0.01$ \\
\hline $\mathrm{C} 18: 3 \alpha$ & 0.54 & 0.47 & 0.53 & 0.45 & 0.02 & 0.29 & $<0.01$ & 0.69 \\
\hline C19:0 & 0.09 & 0.12 & 0.12 & 0.14 & 0.00 & $<0.01$ & 0.01 & 0.68 \\
\hline C19:1 & 0.07 & 0.09 & 0.08 & 0.08 & 0.01 & 0.73 & 0.36 & 0.09 \\
\hline $\mathrm{C} 20: 0$ & 0.14 & 0.14 & 0.20 & 0.16 & 0.01 & $<0.01$ & 0.11 & 0.17 \\
\hline $\mathrm{C} 20: 1$ & 0.22 & 0.36 & 0.42 & 0.50 & 0.02 & $<0.01$ & $<0.01$ & 0.28 \\
\hline $\mathrm{C} 20: 2$ & 0.05 & 0.05 & 0.07 & 0.06 & 0.01 & $<0.01$ & 0.24 & 0.41 \\
\hline C20:3 & 0.15 & 0.11 & 0.12 & 0.12 & 0.01 & 0.40 & 0.17 & 0.08 \\
\hline C20:4 & 0.30 & 0.27 & 0.28 & 0.28 & 0.01 & 0.77 & 0.15 & 0.21 \\
\hline $\mathrm{C} 22: 0$ & 0.02 & 0.02 & 0.04 & 0.03 & 0.01 & 0.03 & 0.28 & 0.62 \\
\hline $\mathrm{C} 22: 1$ & $\mathrm{ND}^{5}$ & 0.01 & 0.05 & 0.02 & 0.00 & $<0.01$ & $<0.01$ & $<0.01$ \\
\hline C20:5n-3 & 0.12 & 0.09 & 0.19 & 0.15 & 0.01 & $<0.01$ & $<0.01$ & 0.22 \\
\hline $\mathrm{C} 22: 3^{*}$ & 0.16 & 0.17 & 0.15 & 0.20 & 0.01 & 0.68 & 0.02 & 0.14 \\
\hline C22:5n-3 & 0.08 & 0.08 & 0.09 & 0.08 & 0.01 & 0.45 & 0.73 & 0.45 \\
\hline $\mathrm{C} 24: 0$ & 0.09 & 0.07 & 0.11 & 0.09 & 0.00 & $<0.01$ & $<0.01$ & 0.06 \\
\hline C24:1 & 0.21 & 0.19 & 0.19 & 0.24 & 0.02 & 0.44 & 0.33 & 0.07 \\
\hline C22:6n-3 & 0.03 & 0.01 & 0.04 & 0.03 & 0.00 & 0.07 & 0.02 & 0.79 \\
\hline Total n-3 FA ${ }^{6 * *}$ & 0.76 & 0.66 & 0.84 & 0.69 & 0.03 & 0.01 & $<0.01$ & 0.28 \\
\hline Total saturated FA & 68.03 & 61.33 & 64.66 & 59.46 & 1.21 & 0.01 & $<0.01$ & 0.45 \\
\hline Total unsaturated FA & 30.50 & 36.21 & 33.09 & 37.81 & 1.17 & 0.03 & $<0.01$ & 0.61 \\
\hline Short $^{7}$ & 9.17 & 7.76 & 8.35 & 7.13 & 0.45 & 0.04 & $<0.01$ & 0.78 \\
\hline Medium $^{8}$ & 56.07 & 49.33 & 54.13 & 49.36 & 0.95 & 0.28 & $<0.01$ & 0.27 \\
\hline Long $^{9}$ & 33.29 & 40.46 & 35.28 & 40.78 & 1.22 & 0.29 & $<0.01$ & 0.44 \\
\hline Others & 1.47 & 2.45 & 2.24 & 2.73 & 0.08 & $<0.01$ & $<0.01$ & $<0.01$ \\
\hline
\end{tabular}

${ }^{1} \mathrm{NFO}=$ no fish oil; $\mathrm{FO}=0.5 \%$ fish oil CDS $=10 \% \mathrm{CDS}$;CDS $=$ no CDS

${ }^{2}$ Expressed as number of carbons: number of double bonds.

${ }^{3} \mathrm{FO}=$ effect of fish oil (FO vs. NFO); CDS = effect of CDS (CDS vs. NCDS), FO $\times$ CDS = interaction of FO and CDS.

${ }^{4}$ See Table 7 for listing of isomers of C18:1 and C18:2.

${ }^{5} \mathrm{ND}=$ not detectable.

${ }^{6}$ Total n-3 FA (C18:3n-3, C20:5n-3, C22:5n-3, and C22:6n-3).

${ }^{7}$ Short-chain fatty acids (C4:0-C10:0).

${ }^{8}$ Medium-chain fatty acids (C11:0-C17:1).

${ }^{9}$ Long-chain fatty acids (C18:0-C22:6).

$*$ Parity $\times$ CDS $(P<0.05)$; **Parity $\times$ FO $(P<0.05)$. 
Table 6. Least squares means for C18:1 and C18:2 isomers in milk fat of cows fed experimental diets ${ }^{1}$

\begin{tabular}{|c|c|c|c|c|c|c|c|c|}
\hline \multirow[b]{2}{*}{ Fatty acid $^{2}$} & \multicolumn{2}{|c|}{ NFO } & \multicolumn{2}{|c|}{ FO } & \multirow[b]{2}{*}{ SEM } & \multicolumn{3}{|c|}{ Effect $^{3}(P$-value $)$} \\
\hline & NCDS & CDS & NCDS & CDS & & FO & CDS & $\mathrm{FO} \times \mathrm{CDS}$ \\
\hline & \multicolumn{4}{|c|}{$-(\mathrm{g} / 100 \mathrm{~g}$ of fatty acids $)$} & & & & \\
\hline Total C18:1 & 20.30 & 25.83 & 21.93 & 26.19 & 1.02 & 0.26 & $<0.01$ & 0.47 \\
\hline Total C18:1 trans & 1.68 & 3.74 & 2.25 & 4.95 & 0.37 & 0.02 & $<0.01$ & 0.34 \\
\hline Total C18:1 cis & 18.62 & 22.09 & 19.68 & 21.24 & 1.02 & 0.78 & $<0.01$ & 0.30 \\
\hline C18:1 trans -4 & 0.03 & 0.05 & 0.03 & 0.04 & 0.01 & 0.63 & 0.06 & 0.46 \\
\hline C18:1 trans- 6 & 0.08 & 0.09 & 0.08 & 0.08 & 0.01 & 0.49 & 0.32 & 0.37 \\
\hline C18:1 trans -8 & 0.02 & 0.06 & 0.02 & 0.05 & 0.01 & 0.75 & 0.05 & 0.82 \\
\hline C18:1 trans -9 & 0.11 & 0.14 & 0.13 & 0.14 & 0.03 & 0.67 & 0.46 & 0.62 \\
\hline $\mathrm{C} 18: 1$ cis- 6 & 0.12 & 0.26 & 0.21 & 0.38 & 0.04 & 0.03 & $<0.01$ & 0.68 \\
\hline $\mathrm{C} 18: 1$ trans -10 & 0.51 & 1.44 & 0.65 & 1.55 & 0.29 & 0.61 & $<0.01$ & 0.95 \\
\hline C18:1 trans-11 & 0.82 & 1.69 & 1.15 & 2.73 & 0.19 & $<0.01$ & $<0.01$ & 0.07 \\
\hline C18:1 cis -9 & 17.79 & 21.37 & 18.86 & 20.42 & 0.94 & 0.95 & $<0.01$ & 0.21 \\
\hline C18:1 cis-11 & 0.83 & 0.72 & 0.82 & 0.82 & 0.06 & 0.34 & 0.25 & 0.25 \\
\hline Total C18:2 & 3.61 & 3.97 & 4.06 & 4.60 & 0.12 & $<0.01$ & $<0.01$ & 0.4 \\
\hline $\mathrm{C} 18: 2$ trans & 0.19 & 0.15 & 0.17 & 0.26 & 0.02 & 0.05 & 0.23 & $<0.01$ \\
\hline C18:2 cis -9, cis -12 & 2.83 & 2.58 & 2.84 & 2.64 & 0.09 & 0.59 & $<0.01$ & 0.68 \\
\hline C18:2 cis-9, trans-11 CLA ${ }^{4}$ & 0.52 & 1.11 & 0.90 & 1.52 & 0.08 & $<0.01$ & $<0.01$ & 0.86 \\
\hline C18:2 trans -10, cis -12 CLA & 0.07 & 0.13 & 0.14 & 0.16 & 0.01 & $<0.01$ & $<0.01$ & 0.11 \\
\hline
\end{tabular}

\footnotetext{
${ }^{1} \mathrm{NFO}=$ No fish oil $; \mathrm{FO}=0.5 \%$ fish oil CDS $=10 \% \mathrm{CDS} ; \mathrm{NCDS}=$ No CDS

${ }^{2}$ Expressed as number of carbons: number of double bonds.

${ }^{3} \mathrm{FO}=$ Effect of fish oil (FO vs. NFO); CDS = effect of CDS (CDS vs. NCDS), FO $\times$ CDS = interaction of FO and CDS.

${ }^{4}$ Conjugated linoleic acid.
}

al. (2005) and Sasikala-Appukuttan et al. (2008) when $10 \%$ CDS was added to the diets.

Concentrations of long-chain fatty acids (C18:0 to C22:6) in milk fat were not affected by the addition of FO to the diets but increased $(P<0.01)$ from 34.3 to $40.6 \mathrm{~g} / 100 \mathrm{~g}$ of fatty acids with the supplementation of CDS to the diets. These results agreed with the findings of Whitlock et al. (2006), who used 0.33 and $0.67 \%$ fish oil and Sasikala-Appukuttan et al. (2008), who fed $10 \%$ CDS in dairy cow rations.

The concentrations of $\mathrm{C} 18: 1$ and $\mathrm{C} 18: 2$ isomers in milk fat are presented in Table 6 . The major isomer of CLA in milk cis-9 trans-11 C18:2 increased $(P<0.01)$ from 0.82 to $1.21 \mathrm{~g} / 100 \mathrm{~g}$ of fatty acids when FO was added to the diets. Similarly, an increase $(P<0.01)$ from 0.71 to $1.32 \mathrm{~g} / 100 \mathrm{~g}$ of fatty acids was noted when CDS was added to the diets. Even though the inclusion of both FO and CDS increased the concentration of cis9 trans-11 CLA, the increase was additive with either FO or CDS alone, with no interaction of FO and CDS. Based on the research of Whitlock et al. (2002), an interaction of FO and CDS might have been expected to occur. Cis-9 trans-11 C18:2 typically comprises 85 to 95\% of the CLA in ruminant milk fat (Chin et al., 1992), which was also true in this experiment.

Two major CLA isomers were identified in milk fat: cis-9 trans-11 C18:2 and trans-10, cis-12 C18:2. Of these, cis-9 trans-11 C18:2 is the most biologically active form of CLA and has been attributed to potential health benefits in humans. Several other studies reported that feeding fish oil with a source rich in linoleic acid to dairy cows could potentially increase milk cis9 trans-11 C18:2 concentrations (Whitlock et al., 2002, 2006; AbuGhazaleh et al., 2003b; Shingfield et al., 2006). Feeding CDS without FO also increased the cis9 trans-11 C18:2 in milk. Sasikala-Appukuttan et al. (2008) also showed an increase from 0.33 to $0.51 \mathrm{~g} / 100$ $\mathrm{g}$ of fatty acids when cows were fed $10 \%$ CDS, which is consistent with our finding. However, we observed a 2.13-fold greater concentration of cis-9 trans- 11 C18:2 CLA in this study $(0.52 \mathrm{~g} / 100 \mathrm{~g}$ of fatty acids with the control diet vs. 1.11 with the CDS diet), which is a greater response than in their experiment.

The concentrations of VA (trans-11 C18:1) in the milk fat were also increased $(P<0.01)$ when FO $(1.26$ vs. $1.94 \mathrm{~g} / 100 \mathrm{~g}$ of fatty acids) or CDS (0.99 vs. $2.21 \mathrm{~g} /$ $100 \mathrm{~g}$ of fatty acids) were added to the diets (Table 6). Supplementation of both FO and CDS to the diets also showed a tendency $(P=0.07)$ for VA to increase in milk. The increase over the control due to both FO and CDS $(1.9 \mathrm{~g} / 100 \mathrm{~g}$ of fatty acids) tended $(P<0.07)$ to be greater than the additive effect of FO and CDS $(1.2 \mathrm{~g} / 110 \mathrm{~g}$ of fatty acids), a response that was hypothesized to occur based on the response when cows were fed fish oil and extruded soybeans (Whitlock et al., 2002). Much of the increase in cis-9 trans-11 C18:2 CLA in the current study was likely due to the endogenous synthesis from trans-11 C18:1 in the mammary gland by $\Delta^{9}$-desaturase 
(Griinari et al., 2000). This close relationship between concentrations of VA as a precursor for synthesis of CLA in milk fat across the diets also explains the increased concentration of cis-9 trans-11 CLA in milk.

The second major CLA isomer, trans-10 cis-12 C18:2, also increased $(P<0.01)$ when FO or CDS was added to the diets. No FO by CDS interaction was noticed for trans-10 cis-12 CLA in this experiment. The current findings are similar to other studies involving diet-induced milk fat depression (Donovan et al., 2000; Da Cruz et al., 2005). Trans-10 cis-12 CLA is considered to be a potential inhibitor of milk fat synthesis as demonstrated with postruminal infusion studies (Baumgard et al., 2002). Previous studies (Whitlock et al., 2002) demonstrated that feeding FO to dairy cows could increase the concentration of trans-10 cis-12 CLA in milk. This correlated with the observed milk fat depression when FO or CDS was added to the diets in the current study. The isomer trans-10 C18:1 was also attributed to cause milk fat depression (Griinari et al., 1998); however, the infusion study by Lock et al. (2007) demonstrated that trans-10 C18:1 had no effect on milk fat depression. The concentration of trans-10 C18:1 in milk also increased $(P<0.01)$ when CDS was added to the diets in this study. It increased when CDS was supplemented, whereas little change occurred when FO was added to the diets. Although an increase in trans10 C18:1 was observed with the inclusion of both FO and CDS in diets, no significant FO by CDS interaction was noted. Increased trans-10 cis-12 C18:2 together with a greater concentration of total C18:1 trans fatty acids were related to the milk fat depression with supplementation of the diets with FO or CDS.

The concentrations of EPA in milk fat increased ( $P$ $<0.01)$ when FO was added to the diets whereas it decreased $(P<0.01)$ with CDS diets (Table 5$)$. Docosahexaenoic acid concentration tended to be greater $(P=$ 0.07 ) in milk from cows fed FO; however, docosahexaenoic acid decreased $(P<0.05)$ with dietary supplementation of CDS. Total n-3 fatty acids in milk increased $(P=0.01)$ with the addition of FO to the diets. These results agreed with the findings of Whitlock et al. (2006), who observed an increase in total n-3 fatty acids when small amounts of FO was fed to dairy cows. Unidentified fatty acids, which are reported as others, also increased $(P<0.01)$ with the addition of FO or CDS or both to the dairy cow diets.

\section{Plasma Fatty Acid Composition}

Unlike milk, plasma fatty acid composition (Table 7) did not differ much between diets except for some key fatty acids, which agreed with the results of Loor et al.
(2005). Greater concentrations of C16:1, trans-11 C18:1, cis-11 C18:1, C18:3n-3, C20:0, C20:1, C22:5n-3, C22:6n3 , and total n-3 were observed in plasma as a result of adding FO to the diets. Feeding FO also resulted in decreased concentrations of C18:0, C18:3n-6, and C20:3; however, the concentrations of EPA, CLA isomers, medium-chain, long-chain, unsaturated, and saturated fatty acids were not affected compared with no FO diets. Supplementation with CDS resulted in greater $(P<0.01)$ plasma concentrations of trans-10 C18:1 and trans-11 C18:1 compared with no CDS diets. Lower concentrations of trans-6 C18:1, C18:3n-6, and C22:4 were observed in cows fed CDS compared with cows fed no CDS. The proportions of C18:3n-3 tended to increase in CDS-fed cows. No FO by CDS interaction was observed for any of the key fatty acids.

The fatty acid profile of milk fat generally agreed with the fatty acid profile of plasma for $\mathrm{C} 16: 1 \mathrm{cis}$, trans$11 \mathrm{C} 18: 1$, cis-11 C18:1, C20:0, C20:1, C22:6n-3, and total n-3 fatty acids in cows fed FO. Greater concentrations of VA in plasma may have accounted for the increase in milk cis-9 trans-11 CLA because of endogenous synthesis from VA in the mammary gland in cows fed FO or CDS. This result supports the view that much of the milk fat cis-9 trans-11 CLA is synthesized from VA in animal tissues such as in the mammary gland via $\Delta^{9}$-desaturase (Bauman et al., 2006). The concentrations of trans-10 C18:1 isomer in milk fat and plasma increased in CDS-fed cows; however, this finding was not observed in cows fed FO. Greater relative percentages of plasma unsaturated fatty acids were noted compared with milk fat unsaturated fatty acids, which might be due to the action of tissue desaturases (Bauman et al., 2006).

\section{Rumen Liquor Analysis}

The results (Table 8) indicated that rumen ammonia concentrations were within a normal range and did not differ among treatments because of similar CP content of diets. Ruminal $\mathrm{pH}$ was measured and was similar for all diets; however, the data are not reported because $\mathrm{pH}$ values obtained via esophageal samples are not always accurate. Ruminal proportions of propionate, isobutyrate, isovalerate, total VFA, and acetate to propionate ratio were similar among diets $(P>0.05)$. Ruminal proportions of acetate were unaffected by the addition of FO; however, acetate tended to $(P=0.08)$ decrease when CDS was added to the diets. Inclusion of CDS to the diets increased $(P<0.01)$ the ruminal proportions of butyrate; however, no effect was found with the addition of FO. Supplementation of FO to the diets increased 
Table 7. Least squares means for fatty acid (FA) composition of plasma from cows fed experimental diets ${ }^{1}$

\begin{tabular}{|c|c|c|c|c|c|c|c|c|}
\hline \multirow[b]{2}{*}{ Fatty acid $^{2}$} & \multicolumn{2}{|c|}{$\mathrm{NFO}$} & \multicolumn{2}{|c|}{ FO } & \multirow[b]{2}{*}{ SEM } & \multicolumn{3}{|c|}{ Effect $^{3}(P$-value $)$} \\
\hline & NCDS & CDS & NCDS & CDS & & FO & CDS & $\mathrm{FO} \times \mathrm{CDS}$ \\
\hline & \multicolumn{2}{|c|}{ - $(\mathrm{g} / 100 \mathrm{~g}$ of FA) - } & & & & & & \\
\hline $\mathrm{C} 12: 0$ & 0.31 & 0.16 & 0.15 & 0.14 & 0.06 & 0.16 & 0.19 & 0.29 \\
\hline C13:0 & 0.08 & 0.38 & 0.06 & 0.25 & 0.14 & 0.61 & 0.09 & 0.67 \\
\hline C14:0 & 0.90 & 0.58 & 0.73 & 0.61 & 0.16 & 0.69 & 0.17 & 0.55 \\
\hline C14:1 trans & 0.21 & 0.23 & 0.26 & 0.25 & 0.02 & 0.08 & 0.74 & 0.38 \\
\hline $\mathrm{C} 14: 1 \mathrm{cis}$ & 0.39 & 0.35 & 0.38 & 0.39 & 0.02 & 0.71 & 0.55 & 0.26 \\
\hline $\mathrm{C} 15: 0$ & 0.48 & 0.39 & 0.48 & 0.40 & 0.02 & 0.71 & $<0.01$ & 0.71 \\
\hline $\mathrm{C} 15: 1$ & 0.22 & 0.18 & 0.21 & 0.18 & 0.01 & 0.98 & 0.02 & 0.88 \\
\hline $\mathrm{C} 16: 0$ & 9.27 & 8.20 & 9.18 & 8.56 & 0.33 & 0.66 & 0.01 & 0.51 \\
\hline C16:1 trans & 0.71 & 0.52 & 0.54 & 0.55 & 0.06 & 0.25 & 0.15 & 0.11 \\
\hline $\mathrm{C} 16: 1 \mathrm{cis}$ & 0.94 & 0.94 & 1.03 & 1.10 & 0.06 & 0.02 & 0.55 & 0.57 \\
\hline C17:0 & 0.80 & 0.77 & 0.69 & 0.71 & 0.09 & 0.25 & 0.92 & 0.75 \\
\hline $\mathrm{C} 17: 1$ & 0.07 & 0.12 & 0.09 & 0.11 & 0.03 & 0.89 & 0.23 & 0.60 \\
\hline C18:0 & 10.19 & 10.70 & 9.97 & 9.41 & 0.35 & 0.03 & 0.95 & 0.12 \\
\hline C18: 1 trans $-6^{*}$ & 0.14 & 0.10 & 0.12 & 0.11 & 0.01 & 0.30 & $<0.01$ & 0.03 \\
\hline $\mathrm{C} 18: 1$ trans $-10^{*}$ & 0.01 & 0.10 & 0.02 & 0.17 & 0.03 & 0.32 & $<0.01$ & 0.36 \\
\hline C18:1 trans -11 & 0.44 & 0.68 & 0.60 & 0.86 & 0.06 & 0.01 & $<0.01$ & 0.91 \\
\hline C18:1 cis -9 & 1.95 & 1.96 & 1.79 & 2.11 & 0.12 & 0.96 & 0.14 & 0.16 \\
\hline C18:1 cis-11 & 0.46 & 0.40 & 0.50 & 0.49 & 0.03 & 0.02 & 0.1 & 0.38 \\
\hline $\mathrm{C} 18: 2$ trans- & 2.26 & 1.47 & 1.56 & 1.43 & 0.19 & 0.07 & 0.02 & 0.10 \\
\hline $\mathrm{C} 18: 2$ cis -9, cis -12 & 34.74 & 35.26 & 36.68 & 34.53 & 0.98 & 0.47 & 0.34 & 0.12 \\
\hline C18:2 cis-9, trans- 11 CLA $^{4}$ & 0.12 & 0.12 & 0.10 & 0.12 & 0.01 & 0.24 & 0.21 & 0.18 \\
\hline C18:2 trans -10, cis $-12 \mathrm{CLA}^{* * *}$ & 0.01 & 0.01 & 0.01 & 0.01 & $<0.01$ & 0.89 & 0.24 & 0.15 \\
\hline $\mathrm{C} 18: 3 \gamma$ & 0.87 & 0.53 & 0.50 & 0.42 & 0.06 & $<0.01$ & $<0.01$ & 0.02 \\
\hline C18:3n-3 & 2.99 & 3.41 & 3.55 & 3.52 & 0.13 & $<0.01$ & 0.09 & 0.06 \\
\hline $\mathrm{C} 19: 0$ & 0.43 & 0.52 & 0.40 & 0.44 & 0.02 & $<0.01$ & $<0.01$ & 0.20 \\
\hline $\mathrm{C} 20: 0$ & 0.06 & 0.05 & 0.07 & 0.10 & $<0.01$ & $<0.01$ & 0.53 & 0.03 \\
\hline $\mathrm{C} 20: 1$ & 0.20 & 0.23 & 0.27 & 0.37 & 0.04 & 0.02 & 0.11 & 0.45 \\
\hline $\mathrm{C} 20: 2$ & 0.15 & 0.13 & 0.13 & 0.11 & 0.02 & 0.44 & 0.34 & 0.92 \\
\hline $\mathrm{C} 20: 3$ & 1.50 & 1.32 & 1.08 & 1.02 & 0.07 & $<0.01$ & 0.04 & 0.33 \\
\hline C20:4 & 1.67 & 1.58 & 1.63 & 1.69 & 0.09 & 0.62 & 0.84 & 0.23 \\
\hline $\mathrm{C} 22: 0$ & 0.06 & 0.07 & 0.03 & 0.14 & 0.02 & 0.42 & 0.04 & 0.07 \\
\hline $\mathrm{C} 20: 3$ & 0.14 & 0.13 & 0.12 & 0.10 & 0.01 & 0.25 & 0.44 & 0.75 \\
\hline $\mathrm{C} 22: 1$ & 0.07 & 0.06 & 0.07 & 0.08 & $<0.01$ & 0.33 & 0.76 & 0.15 \\
\hline C20:5n-3 & 1.82 & 1.81 & 1.94 & 2.03 & 0.14 & 0.22 & 0.75 & 0.71 \\
\hline C22:3* & 0.20 & 0.20 & 0.20 & 0.21 & 0.01 & 0.76 & 0.76 & 0.50 \\
\hline $\mathrm{C} 22: 4$ & 0.45 & 0.42 & 0.43 & 0.37 & 0.01 & 0.04 & $<0.01$ & 0.31 \\
\hline C22:5n-6 & 7.15 & 7.58 & 7.06 & 7.84 & 0.31 & 0.79 & 0.06 & 0.58 \\
\hline $\mathrm{C} 22: 5 \mathrm{n}-3$ & 0.49 & 0.46 & 0.61 & 0.56 & 0.03 & $<0.01$ & 0.19 & 0.68 \\
\hline C24:0 & 0.34 & 0.26 & 0.29 & 0.23 & 0.02 & 0.10 & 0.01 & 0.71 \\
\hline $\mathrm{C} 24: 1$ & 16.58 & 17.49 & 16.07 & 17.91 & 0.76 & 0.95 & 0.08 & 0.54 \\
\hline C22:6n-3 & 0.15 & 0.15 & 0.33 & 0.33 & 0.02 & $<0.01$ & 0.99 & 0.91 \\
\hline Medium $^{5}$ & 14.37 & 12.84 & 13.84 & 13.26 & 0.59 & 0.93 & 0.08 & 0.41 \\
\hline Long ${ }^{6}$ & 85.63 & 87.16 & 86.16 & 86.74 & 0.59 & 0.93 & 0.08 & 0.41 \\
\hline Total n-3 ${ }^{7}$ & 5.45 & 5.83 & 6.43 & 6.44 & 0.21 & $<0.01$ & 0.29 & 0.32 \\
\hline Saturated FA & 22.90 & 22.07 & 22.08 & 21.00 & 0.67 & 0.15 & 0.15 & 0.85 \\
\hline Unsaturated FA & 77.10 & 77.93 & 77.92 & 79.00 & 0.67 & 0.15 & 0.15 & 0.85 \\
\hline
\end{tabular}

\footnotetext{
${ }^{1} \mathrm{NFO}=$ no fish oil $; \mathrm{FO}=0.5 \%$ fish oil CDS $=10 \% \mathrm{CDS} ; \mathrm{NCDS}=$ no CDS.

${ }^{2}$ Expressed as number of carbons: number of double bonds.

${ }^{3} \mathrm{FO}=$ effect of fish oil (FO vs. NFO); CDS = effect of CDS (CDS vs. NCDS); FO CDS = interaction of FO and CDS.

${ }^{4}$ Conjugated linoleic acid.

${ }^{5}$ Medium-chain fatty acids (C12:0-C17:1).

${ }^{6}$ Long-chain fatty acids (C18:0-C22:6).

${ }^{7}$ Total n-3 FA (C18:3n-3, C20:5n-3, C22:5n-3, and C22:6n-3).

$*$ Interaction of parity $\times \mathrm{CDS} ; * * *$ interaction of parity $\times \mathrm{FO} \times \mathrm{CDS}$.
}

$(P<0.01)$ ruminal proportions of valerate. In general, the ruminal ammonia and VFA data did not appear to influence milk fatty acid data, which was the main thrust of this experiment.

\section{CONCLUSIONS}

This study indicated that adding FO or CDS to dairy cow diets resulted in greater concentrations of cis-9 
Table 8. Least squares means for ruminal ammonia and VFA concentrations for cows fed experimental $\operatorname{diets}^{1}$

\begin{tabular}{|c|c|c|c|c|c|c|c|c|}
\hline \multirow[b]{2}{*}{ Item } & \multicolumn{2}{|c|}{ NFO } & \multicolumn{2}{|c|}{ FO } & \multirow[b]{2}{*}{ SEM } & \multicolumn{3}{|c|}{ Effect $^{2}$ ( $P$-value $)$} \\
\hline & NCDS & CDS & NCDS & CDS & & FO & CDS & $\mathrm{FO} \times \mathrm{CDS}$ \\
\hline $\mathrm{NH}_{3}, \mathrm{mg} / \mathrm{dL}$ & 4.5 & 6.4 & 5.4 & 4.3 & 0.93 & 0.55 & 0.65 & 0.10 \\
\hline Total VFA, mM & 61.7 & 63.5 & 61.2 & 62.5 & 5.71 & 0.88 & 0.78 & 0.97 \\
\hline Acetate & 60.1 & 58.6 & 61.2 & 59.8 & 0.82 & 0.16 & 0.08 & 0.93 \\
\hline Propionate & 23.1 & 23.7 & 22.8 & 23.0 & 1.01 & 0.55 & 0.66 & 0.83 \\
\hline Butyrate & 12.3 & 13.3 & 11.6 & 12.9 & 0.54 & 0.17 & $<0.01$ & 0.79 \\
\hline Isobutyrate* & 1.2 & 1.2 & 1.2 & 1.4 & 0.08 & 0.48 & 0.52 & 0.17 \\
\hline Isovalerate* & 1.7 & 1.6 & 1.8 & 1.7 & 0.08 & 0.23 & 0.35 & 0.73 \\
\hline Valerate & 1.6 & 1.6 & 1.3 & 1.5 & 0.07 & $<0.01$ & 0.11 & 0.68 \\
\hline Acetate:propionate & 2.7 & 2.5 & 2.9 & 2.7 & 0.17 & 0.28 & 0.14 & 0.79 \\
\hline
\end{tabular}

${ }^{1} \mathrm{NFO}=$ no fish oil $; \mathrm{FO}=0.5 \%$ fish oil CDS $=10 \% \mathrm{CDS} ; \mathrm{NCDS}=$ no CDS.

${ }^{2} \mathrm{FO}=$ effect of fish oil (FO vs. NFO); CDS = effect of CDS (CDS vs. NCDS), FO $\times$ CDS = interaction of FO and CDS.

$*$ Interaction of parity $\times \mathrm{FO} \times \mathrm{CDS}(P<0.05)$.

trans-11 CLA and trans-11 C18:1 in milk fat without affecting milk yield and DMI; no interactions were observed between FO and CDS on cis-9 trans-11 CLA although vaccenic acid tended to be higher with the interaction. Greater concentrations of trans-11 C18:1 in plasma relative to cis-9 trans-11 CLA compared with their relative concentrations in milk fat suggested that there was a tissue synthesis of cis-9 trans-11 CLA in mammary gland via $\Delta^{9}$ - desaturase or differential uptake. Feeding cows a low amount $(0.5 \%)$ of fish oil enhanced the functional benefit of milk because of increased concentrations of $n-3$ fatty acids and cis-9 trans11 CLA in milk fat; however, some milk fat depression occurred due to feeding FO or CDS.

\section{ACKNOWLEDGMENTS}

The authors gratefully acknowledge the farm crew at the South Dakota State University Dairy Research Unit for care of the cows and assistance with data collection. The authors also wish to acknowledge the South Dakota Corn Utilization Council (Sioux Falls, SD) for partial financial support, Poet Nutrition (Sioux Falls, SD) for supplying CDS, and Omega Protein International (Hammond, LA) for menhaden fish oil.

\section{REFERENCES}

Abu-Ghazaleh, A. A., D. J. Schingoethe, A. R. Hippen, and L. A. Whitlock. 2002. Feeding fish meal and extruded soybeans enhances the conjugated linoleic acid (CLA) content of milk. J. Dairy Sci. 85:624-631.

AbuGhazaleh, A. A., D. J. Schingoethe, A. R. Hippen, and K. F. Kalscheur. 2003a. Milk conjugated linoleic acid response to fish oil supplementation of diets differing in fatty acid profiles. J. Dairy Sci. 86:944-953.

AbuGhazaleh, A. A., D. J. Schingoethe, A. R. Hippen, and K. F. Kalscheur. 2003b. Conjugated linoleic acid and vaccenic acid in rumen, plasma, and milk of cows fed fish oil and fats differing in saturation of 18 carbon fatty acids. J. Dairy Sci. 86:3648-3660.

Anderson, J. L., D. J. Schingoethe, K. F. Kalscheur, and A. R. Hippen. 2006. Evaluation of dried and wet distillers grains included at two concentrations in the diets of lactating dairy cows. J. Dairy Sci. 89:3133-3142.

Association of Official Analytical Chemists. 2002. Official Methods of Analysis. 17th ed. AOAC, Gaithersburg, MD.

Bauman, D. E., I. H. Mather, R. J. Wall, and A. L. Lock. 2006. Major advances associated with the biosynthesis of milk. J. Dairy Sci. 89:1235-1243.

Baumgard, L. H., E. Matitashvili, B. A. Corl, D. A. Dwyer, and D. E. Bauman. 2002. Trans-10, cis-12 conjugated linoleic acid decreases lipogenic rates and expression of genes involved in milk lipid synthesis in dairy cows. J. Dairy Sci. 85:2155-2163.

Cant, J. P., A. H. Fredeen, T. MacIntyre, J. Gunn, and N. Crowe. 1997. Effect of fish oil and monensin on milk fat composition in dairy cows. Can. J. Anim. Sci. 77:125-131.

Chaney, A. L., and E. P. Marbach. 1962. Modified reagents for determination of urea and ammonia. Clin. Chem. 8:130-132.

Chillard, Y. A. F., and M. Doreau. 2001. Effect of different types of forages, animal fat or marine oils in cow's diet on milk fat secretion and composition, especially conjugated linoleic acid (CLA) and polyunsaturated fatty acids. Livest. Prod. Sci. 70:31-48.

Chin, S. F., W. Liu, J. M. Storkson, Y. L. Ha, and M. W. Pariza. 1992 Dietary sources of conjugated dienoic isomers of linoelic acid, a newly recognized class of anticarcinogens. J. Food Comp. Anal. 5:185-197.

Chouinard, P. Y., L. Corneau, D. M. Barbano, L. E. Metzger, and D. E. Bauman. 1999. Conjugated linoleic acids alter milk fatty acid composition and inhibit milk fat secretion in dairy cows. J. Nutr. 129:1579-1584.

Chouinard, P. Y., L. Corneau, W. R. Butler, D. E. Bauman, Y. Chilliard, and J. K. Drackley. 2001. Effect of dietary lipid source on conjugated linoleic acid concentrations in milk fat. J. Dairy Sci. 84:680-690

Da Cruz, C. R., M. J. Brouk, and D. J. Schingoethe. 2005. Lactational response of cows fed condensed corn distillers solubles. J. Dairy Sci. 88:4000-4006.

Donovan, D. C., D. J. Schingoethe, R. J. Baer, J. Ryali, A. R. Hippen, and S. T. Franklin. 2000. Influence of dietary fish oil on conjugated linoleic acid and other fatty acids in milk fat from lactating dairy cows. J. Dairy Sci. 83:2620-2628.

Griinari, J. M., B. A. Corl, S. H. Lacy, P. Y. Chouinard, K. V. V. Nurmela, and D. E. Bauman. 2000. Conjugated linoleic acid is synthesized endogenously in lactating dairy cows by $\Delta^{9}$-desaturase. J. Nutr. 130:2285-2291. 
Griinari, J. M., D. A. Dwyer, M. A. McGuire, D. E. Bauman, D. L. Palmquist, and K. V. V. Nurmela. 1998. Trans-octadecenoic acids and milk fat depression in lactating dairy cows. J. Dairy Sci. 81:1251-1261.

Jenkins, T. C., and B. F. Jenny. 1989. Effect of hydrogenated fat on feed intake, nutrient digestion, and lactation performance of dairy cows. J. Dairy Sci. 72:2316-2324.

Lock, A. L., C. Tyburczy, D. A. Dwyer, K. J. Harvatine, F. Destaillats, Z. Mouloungui, L. Candy, and D. E. Bauman. 2007. Trans-10 octadecenoic acid does not reduce milk fat synthesis in dairy cows. J. Nutr. 137:71-76.

Loor, J. J., A. Ferlay, A. Ollier, M. Doreau, and Y. Chilliard. 2005. Relationship among trans and conjugated fatty acids and bovine milk fat yield due to dietary concentrate and linseed oil. J. Dairy Sci. 88:726-740.

Lowry, J. B., L. L. Conlan, A. A. Schlink, and C. S. McSweeny. 1994. Acid detergent dispersible lignin in tropical grasses. J. Food Agric. 65:41-50.

National Research Council. 2001. Nutrient Requirements of Dairy Cattle. 7th rev. ed. Natl. Acad. Sci., Washington, DC.

Offer, N. W., M. Marsden, J. Dixon, B. K. Speake, and F. E. Thacker. 1999. Effect of dietary fat supplements on levels of $n$-3 polyunsaturated fatty acids, trans acids and conjugated linoleic acid in bovine milk. Anim. Sci. 69:613-625.

Orth, R. 1992. Sample day and lactation report. DHIA 200 Fact Sheet A-2, Mid-states DRPC, Ames, IA.

Ottenstein, D. M., and D. A. Bartley. 1971. Separation of free acids C2 - C5 in dilute aqueous solution column technology. J. Chromatogr. Sci. 9:673-681.

Robertson, J. B., and P. J. Van Soest. 1981. The detergent system of analysis and its application to human foods. Pages 123-158 in The Analysis of Dietary Fiber in Food. W. P. T. James and O. Theander, ed. Marcel Dekker Inc., New York, NY.

SAS Institute. 1999. User's Guide: Statistics. Version 8.01 ed. SAS Institute Inc., Cary, NC.
Sasikala-Appukuttan, A. K., D. J. Schingoethe, A. R. Hippen, K. F. Kalscheur, K Karges, and M. L. Gibson. 2008. The feeding value of corn distillers solubles for lactating dairy cows. J. Dairy Sci. 91:279-287.

Schingoethe, D. J., M. J. Brouk, K. D. Lightfield, and R. J. Baer. 1996. Lactational responses of dairy cows fed unsaturated fat from extruded soybeans or sunflower seeds. J. Dairy Sci. 79:1244-1249.

Shingfield, K. J., C. K. Reynolds, G. Hervás, J. M. Griinari, A. S. Grandison, and D. E. Beever. 2006. Examination of the persistency of milk fatty acid composition responses to fish oil and sunflower oil in the diet of dairy cows. J. Dairy Sci. 89:714-732.

Sukhija, P. S., and D. L. Palmquist. 1988. A rapid method for determination of total fatty acid content and composition of feedstuffs and feces. J. Agric. Food Chem. 36:1202-1206.

Understander, D., D. R. Mertens, and N. Thiex. 1993. Forage analysis procedures. National Forage Testing Association, Omaha, Nebraska.

Van Soest, P. J., J. B. Robertson, and B. A. Lewis. 1991. Methods for dietary fiber, neutral detergent fiber, and nonstarch polysaccharides in relation to animal nutrition. J. Dairy Sci. 74:35833597.

Whitlock, L. A., D. J. Schingoethe, A. A. AbuGhazaleh, A. R. Hippen, and K. F. Kalscheur. 2006. Milk production and composition from cows fed small amounts of fish oil with extruded soybeans. J. Dairy Sci. 89:3972-3980.

Whitlock, L. A., D. J. Schingoethe, A. R. Hippen, K. F. Kalscheur, R. J. Baer, N. Ramaswamy, and K. M. Kasperson. 2002. Fish oil and extruded soybeans fed in combination increase conjugated linoleic acids in milk of dairy cows more than when fed separately. J. Dairy Sci. 85:234-243.

Wildman, E. E., G. M. Jones, P. E. Wagner, R. L. Boman, H. F. Troutt Jr., and T. N. Lesch. 1982. A dairy cow body condition scoring system and its relationship to standard production characteristics. J. Dairy Sci. 65:495-501. 